\title{
Restricting Phosphorous Can Manage Growth and Development of Containerized Sweet Basil, Dill, Parsley, and Sage
}

\author{
Christopher J. Currey, Vincent C. Metz, Nicholas J. Flax, \\ and Alex G. Litvin \\ Department of Horticulture, Iowa State University, 2206 Osborn Drive, \\ Ames, IA 50011
}

Brian E. Whipker

Department of Horticulture, North Carolina State University, 2721 Founders Drive, Raleigh, NC 27695

Additional index words. Anethum graveolens, culinary herbs, growth regulation, mineral nutrition, nonchemical, Ocimum basilicum, Petroselinum crispum, Salvia officinalis

\begin{abstract}
The objective of this research was to quantify the effects of phosphorous (P) concentrations on the growth, development, and tissue mineral nutrient concentrations of four popular culinary herbs commonly grown in containers. Seedlings of sweet basil (Ocimum basilicum 'Italian Large Leaf'), dill (Anethum graveolens 'Fernleaf'), parsley (Petroselinum crispum 'Giant of Italy'), and sage (Salvia officinalis) were individually transplanted to 11.4-cm-diameter containers filled with soilless substrate comprising canadian sphagnum peatmoss and coarse perlite. Upon transplanting and throughout the experiment, seedlings were irrigated with solutions containing $0,5,10,20$, or $40 \mathrm{mg} \cdot \mathrm{L}^{-1}$ $P$; all other macro- and micronutrient concentrations were the same across $P$ concentrations. Plants were grown for 4 weeks in a greenhouse; after that time, data were collected. Relationships between height and width and $P$ concentrations were nonlinear for all four species; height and width increased as $P$ increased to more than $0 \mathrm{mg} \cdot \mathrm{L}^{-1}$ until the speciesspecific maxima; after that time, no further increase occurred. The same trend was observed for the branch length of sweet basil and sage, and for internode length, leaf area, and shoot dry mass of all four species. Although visible $P$ deficiency symptoms were observed for plants provided with $0 \mathrm{mg} \cdot \mathrm{L}^{-1} \mathrm{P}$, there were no signs of $P$ deficiency for plants provided with $\geq 5$ mg. $L^{-1} P$, even though tissue $P$ concentrations were below the recommended sufficiency ranges. As a result of this research, containerized sweet basil, dill, parsley, and sage can be provided with 5 to $10 \mathrm{mg} \cdot \mathrm{L}^{-1} P$ during production to limit growth and produce plants without visible nutrient deficiency symptoms that are proportional to their containers.
\end{abstract}

Whether used as bedding plants or as indoor containerized plants, live culinary herbs are a popular containerized plant. It is important to control shoot growth to produce

Received for publication 22 Jan. 2020. Accepted for publication 6 Mar. 2020.

Published online 14 October 2020.

C.J.C. is an Associate Professor.

V.C.M. is a Former Undergraduate Research Assistant.

N.J.F. and A.G.L. are Former Graduate Research Assistants.

B.E.W. is a Professor.

We gratefully acknowledge Peter Lawlor for greenhouse assistance.

The use of trade names in this publication does not imply endorsement by Iowa State University and North Carolina State University of products named nor criticism of similar ones not mentioned.

C.J.C. is the corresponding author. E-mail: ccurrey@ iastate.edu.

This is an open access article distributed under the CC BY-NC-ND license (https://creativecommons. org/licenses/by-nc-nd/4.0/). useful for controlling containerized herb growth. While not common for many annual herbs, there are compact sweet basil and dill cultivars, although the selection is limited (Currey and Mazur, 2018). Sweet basil (Ocimum basilicum) grown with a zero-difference between the day and night air temperatures (DIF; DIF = day temperature - night temperature) or a morning drop can inhibit basil height compared with plants grown with a positive DIF (Islam et al., 2016). Brushing can suppress containerized sweet basil, cilantro (Coriandrum sativum), and parsley (Petroselinum crispum) growth (Appling, 2012). Maintaining the substrate moisture content of containerized sweet basil, dill (Anethum graveolens), parsley, and sage (Salvia officinalis) at $40 \%$ to $50 \%$ less (by volume) than well-watered plants also suppresses growth (Currey et al., 2019). Additionally, applying 50 or $100 \mathrm{mg} \cdot \mathrm{L}^{-1} \mathrm{~N}$ to watersoluble fertilizer or 0.6 to $1.5 \mathrm{~kg} \cdot \mathrm{m}^{-3}$ of controlled-release fertilizer can produce healthy-looking plants without excessive size (Flax and Currey, 2016). However, in addition to the total fertilizer concentration directly affecting plant growth, $\mathrm{P}$ affects the growth and development of herbaceous plants.

Phosphorous has a growth-promoting effect up to the species-specific maxima; therefore, restricting P can restrict growth (Frantz, 2013; Henry et al., 2017, 2018a; Justice and Faust, 2015; Nelson et al., 2012). Initial studies that have identified the effect of $\mathrm{P}$ on stem elongation and subsequent use of $\mathrm{P}$ restriction to suppress growth were focused on seedling plugs (Nelson et al., 2012). Because of the effectiveness of $\mathrm{P}$ restriction to restrict seedling growth, it has become a widely adopted practice for commercial plug producers (Whipker, 2014). More recently, restricting $P$ fertilization for growth control has been extended to the finished production of containerized plants (Henry et al., 2017, 2018a; Justice and Faust, 2015). Although containerized plant P restriction research is focused on flowering ornamental species, $\mathrm{P}$ restriction could also be used for finishing containerized culinary herbs. However, we have found no research quantifying the effects of $\mathrm{P}$ on containerized culinary herb growth and development.

The objective of this experiment was to quantify the effects of $\mathrm{P}$ concentrations on the growth and development of four popular culinary herbs. We hypothesized that restricted $\mathrm{P}$ would suppress containerized herb growth and that the magnitude of the effects would vary among the different species of the study. To test our hypothesis, we formulated nutrient solutions varying only in their $\mathrm{P}$ concentration to provide a range of $\mathrm{P}$ concentrations; they ranged from no $\mathrm{P}$ to the maximum concentration, representing standard greenhouse practices, for containerized herbs during their greenhouse finishing or forcing period.

\section{Materials and Methods} ing irrigation (Alem et al., 2015) and mineral nutrients (Whipker et al., 1999). Although more widely used for ornamental flowering plants, several of these techniques are also
Seeds (Johnny's Selected Seed, Albion, ME) of sweet basil 'Italian Large Leaf', dill 
Table 1. Nitrogen $(\mathrm{N})$, phosphorous $(\mathrm{P})$, potassium $(\mathrm{K})$, calcium $(\mathrm{Ca})$, magnesium $(\mathrm{Mg})$, sulfur $(\mathrm{S})$, boron $(\mathrm{B})$, copper $(\mathrm{Cu})$, iron $(\mathrm{Fe})$, manganese $(\mathrm{Mn})$, molybdenum (Mo), and zinc $(\mathrm{Zn})$ concentrations of fertilizer solution during the seedling propagation and finishing growth stages provided to sweet basil (Ocimum basilicum 'Italian Large Leaf'), dill (Anethum graveolens 'Fernleaf'), parsley (Petroselinum crispum 'Giant of Italy'), and sage (Salvia officinalis). During finishing, nutrient solutions were formulated to provide varying $\mathrm{P}$ concentrations.

\begin{tabular}{|c|c|c|c|c|c|c|c|c|c|c|c|c|}
\hline \multirow[b]{2}{*}{$\mathrm{P}$ treatment $\left(\mathrm{mg} \cdot \mathrm{L}^{-1}\right)$} & \multicolumn{12}{|c|}{ Nutrient concn $\left(\mathrm{mg} \cdot \mathrm{L}^{-1}\right)$} \\
\hline & $\mathrm{N}$ & $\mathrm{P}$ & $\mathrm{K}$ & $\mathrm{Ca}$ & $\mathrm{Mg}^{\mathrm{z}}$ & $\mathrm{S}^{\mathrm{z}}$ & B & $\mathrm{Cu}$ & $\mathrm{Fe}$ & $\mathrm{Mn}$ & Mo & $\mathrm{Zn}$ \\
\hline- & \multicolumn{12}{|c|}{ Finishing } \\
\hline 5 & 150.0 & 5.0 & 150.0 & 128.6 & 50.0 & 56.1 & 0.05 & 0.12 & 0.28 & 0.09 & 0.01 & 0.12 \\
\hline 10 & 150.0 & 10.0 & 150.0 & 128.6 & 53.2 & 57.7 & 0.05 & 0.12 & 0.28 & 0.09 & 0.01 & 0.12 \\
\hline 20 & 150.0 & 20.0 & 150.0 & 128.6 & 54.2 & 53.9 & 0.05 & 0.12 & 0.28 & 0.09 & 0.01 & 0.12 \\
\hline
\end{tabular}

${ }^{\mathrm{z}}$ To create a range of $\mathrm{P}$ concentrations in the fertilizer treatments during the finishing stage of growth, $\mathrm{Mg}$ and $\mathrm{S}$ concentrations varied to achieve target $\mathrm{P}$ treatments.
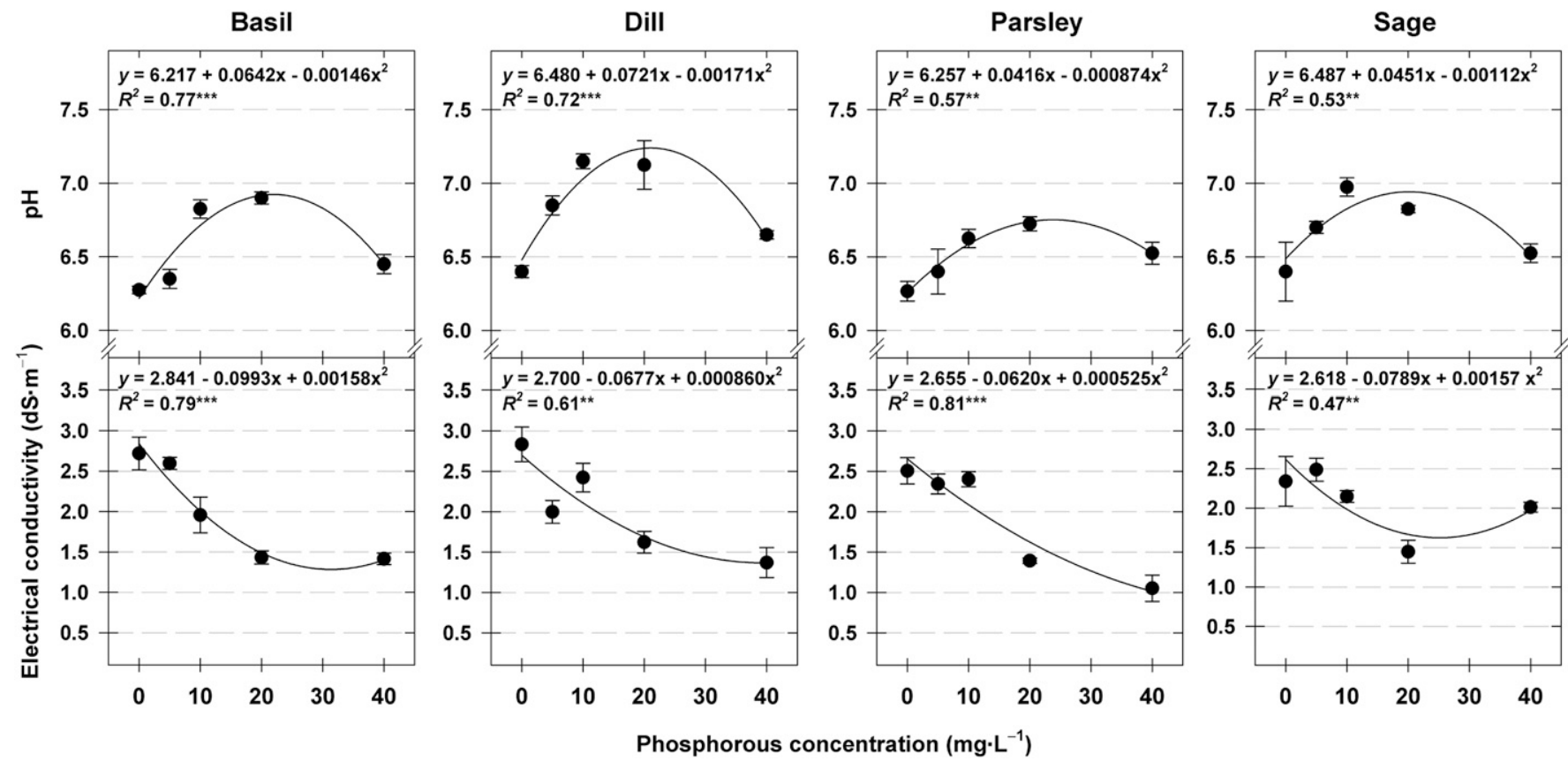

Fig. 1. Final pH and electrical conductivity of sweet basil (Ocimum basilicum 'Italian Large Leaf'), dill (Anethum graveolens 'Fernleaf'), parsley (Petroselinum crispum 'Giant of Italy'), and sage (Salvia officinalis) grown in 11.4-cm-diameter containers and provided with nutrient solutions containing 0 to $40 \mathrm{mg} \cdot \mathrm{L}^{-1}$ phosphorous (P). Data were collected 4 weeks after transplanting seedlings. Each symbol represents the mean of four replications, with each consisting of one sample (individual plant container) per replication. $* *$ or $* * *$ indicate significance at $P \leq 0.01$ or 0.001 , respectively.

'Fernleaf', parsley 'Giant of Italy', and sage were individually sown in 288 -cell propagation trays (PL-288-1.25; 7.1- $\mathrm{cm}^{3}$ individual cell volume; T.O. Plastics, Clearwater, $\mathrm{MN}$ ) filled with a soilless germination substrate (Propagation Mix; Sun Gro Horticulture, Agawam, MA). Trays were initially hand-irrigated with clear, tempered tap water. Beginning at radicle emergence, seedlings were irrigated with tap water supplemented with a modified all-nitrate Hoagland's nutrient solution (Table 1) comprising technical-grade calcium nitrate, potassium nitrate, magnesium sulfate, monopotassium phosphate, potassium sulfate, magnesium nitrate, manganese chloride, zinc chloride, copper chloride, and sodium molybdate (Fisher Scientific, Hampton, NH).

Seedlings were grown on expanded metal benches in a glass-glazed greenhouse at Iowa State University in Ames, IA (latitude $42^{\circ} \mathrm{N}$ ) with fog cooling, radiant hot water floor and perimeter heating, and retractable shade cur- tains controlled by an environmental computer (ARGUS Titan; ARGUS Control Systems, Surrey, BC, Canada). The day and night greenhouse air temperature set points were $23.0 \pm 1{ }^{\circ} \mathrm{C}$ and $18.0 \pm 1{ }^{\circ} \mathrm{C}$, respectively. Aluminized shadecloth (XLS 15 Revolux; Ludvig Svensson, Kinna, Sweden) was drawn across the crop when outdoor light intensities exceeded $1000 \mu \mathrm{mol} \cdot \mathrm{m}^{-2} \cdot \mathrm{s}^{-1}$ to avoid leaf scorch. High-pressure sodium lamps delivered a supplemental photosynthetic photon flux density $(P P F D)$ of $\approx 190$ $\mu \mathrm{mol} \cdot \mathrm{m}^{-2} \cdot \mathrm{s}^{-1}$ at plant height as measured with a quantum sensor (LI-190 SB; LICOR Biosciences, Lincoln, NE) when the ambient light intensity was less than 100 $\mu \mathrm{mol} \cdot \mathrm{m}^{-2} \cdot \mathrm{s}^{-1}$ between 0600 and $2200 \mathrm{HR}$ to maintain a target daily light integral (DLI) of $\approx 12 \mathrm{~mol} \cdot \mathrm{m}^{-2} \cdot \mathrm{d}^{-1}$.

Seedlings were transplanted to $11.4-\mathrm{cm}$ diameter containers filled with soilless substrate comprising (by volume) $80 \%$ canadian sphagnum peatmoss (Conrad Fafard, Agawam,
MA) moistened with deionized (DI) water containing $300 \mathrm{mg} \cdot \mathrm{L}^{-1}$ of a wetting agent (Capsil; Auqatrols, Paulsboro, NJ) and 20\% coarse perlite (Therm-O-Rock East, New Eagle, PA) and amended with $1.7 \mathrm{~kg} \cdot \mathrm{m}^{-3}$ calcitic limestone (Mississippi Lime Company, Alton, IL) to achieve a final $\mathrm{pH}$ of $\approx 5.6$ to 5.8 at 4 weeks after seeds were sown. Substrate was mixed and allowed to equilibrate for 3 weeks before filling containers and planting seedlings.

Upon transplanting in final containers, seedlings were irrigated with solutions containing $150 \mathrm{mg} \cdot \mathrm{L}^{-1}$ nitrogen $(\mathrm{N})$ and $0,5,10$, 20 , or $40 \mathrm{mg} \cdot \mathrm{L}^{-1} \mathrm{P}$. To create fertilizer solutions with a range of $\mathrm{P}$ concentrations and comparable macro- and micronutrient concentrations, technical-grade salts (Fisher Scientific) were used as previously described. Most macronutrient concentrations and all micronutrient concentrations were the same across $P$ treatments (Table 1). However, magnesium $(\mathrm{Mg})$ and sulfur $(\mathrm{S})$ concentrations 
Basil

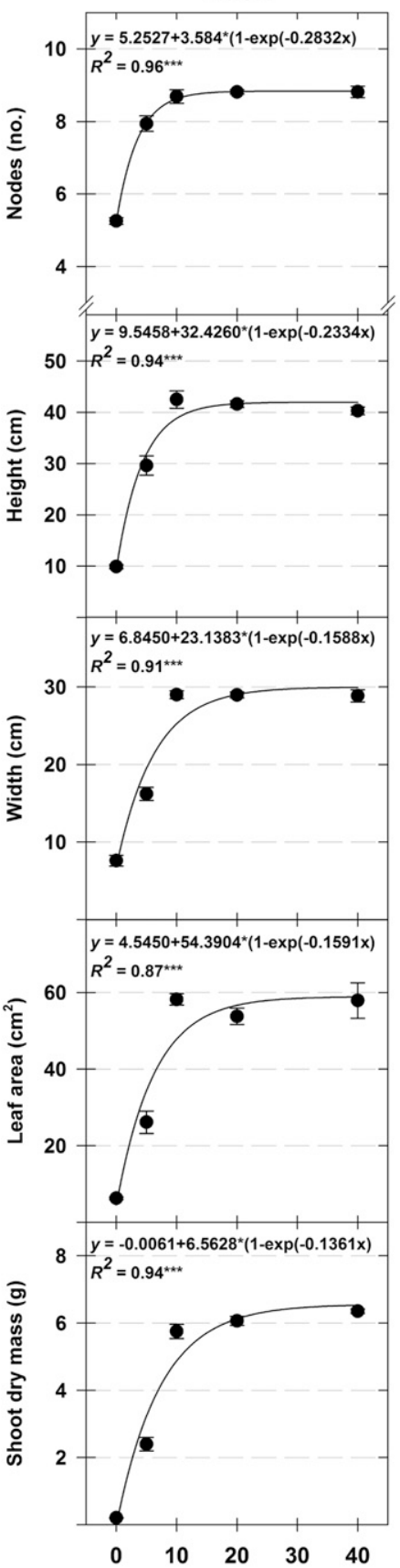

Dill
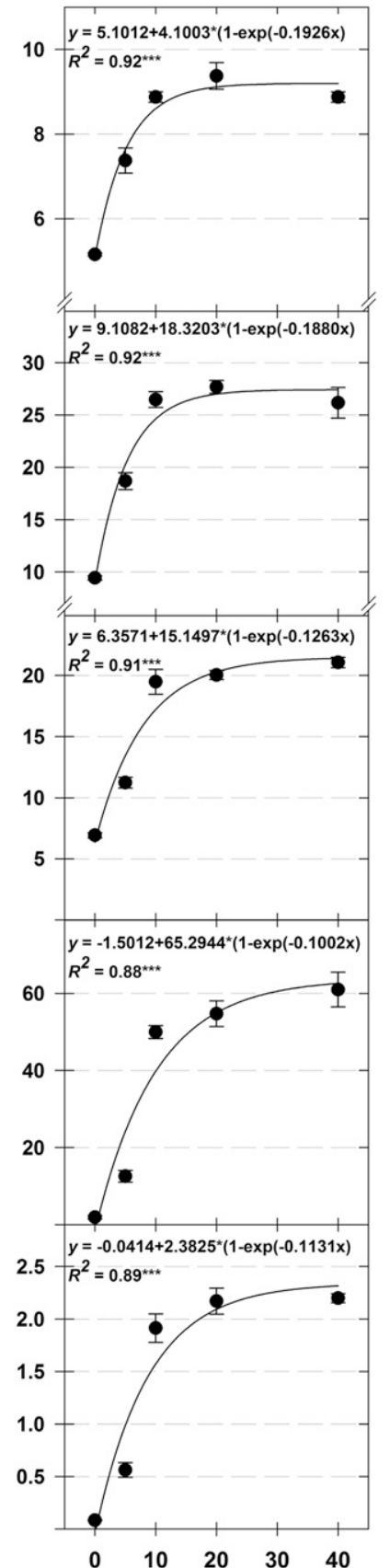

Parsley
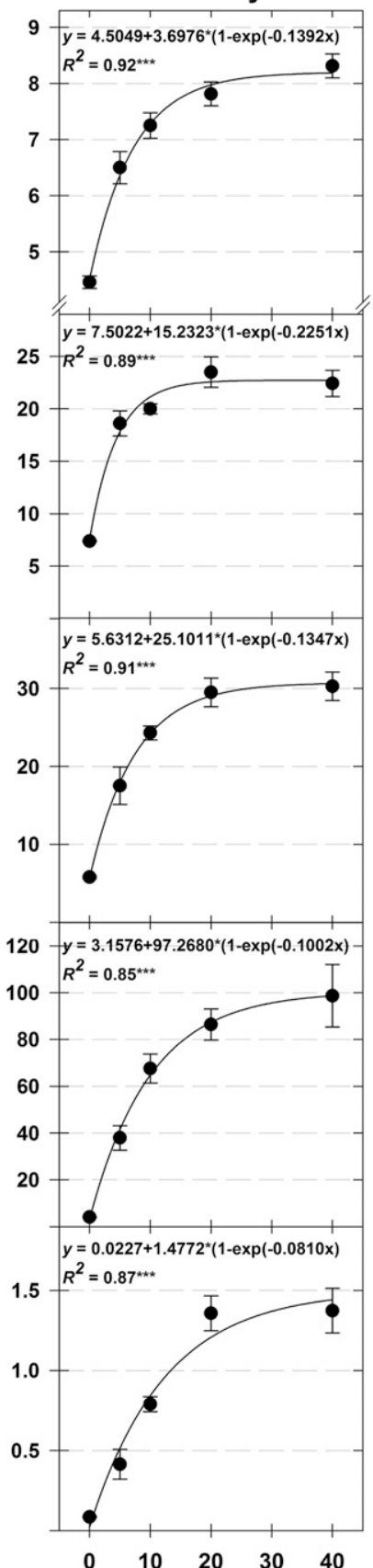

Sage
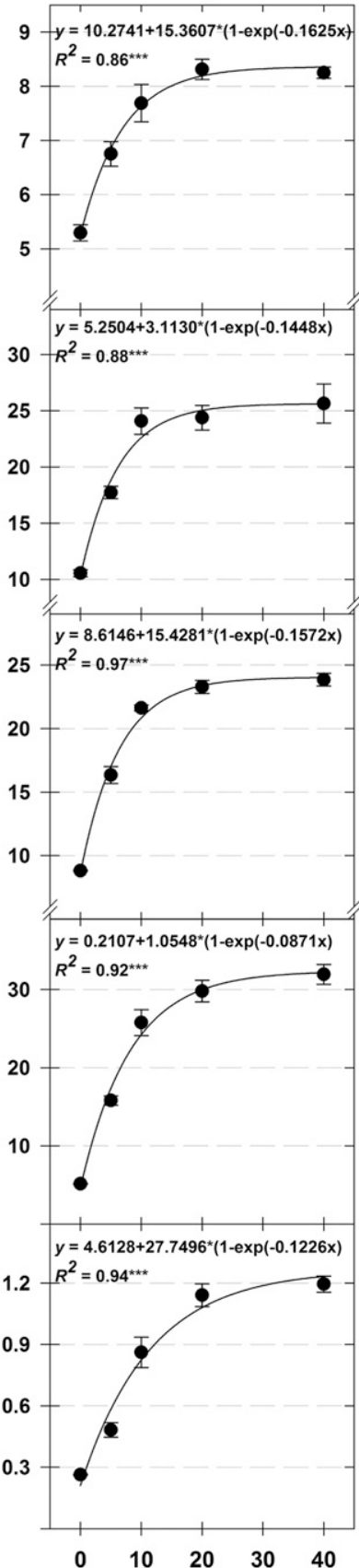

Phosphorous concentration $\left(\mathrm{mg} \cdot \mathrm{L}^{-1}\right)$

Fig. 2. Node number, height, width, shoot dry mass, and leaf area of sweet basil (Ocimum basilicum 'Italian Large Leaf'), dill (Anethum graveolens 'Fernleaf'), parsley (Petroselinum crispum 'Giant of Italy'), and sage (Salvia officinalis) grown in 11.4-cm-diameter containers and provided with nutrient solutions containing 0 to $40 \mathrm{mg} \cdot \mathrm{L}^{-1}$ phosphorous (P). Data were collected 4 weeks after transplanting seedlings. Each symbol represents the mean of four replications, with each consisting of $8\left(0 \mathrm{mg} \cdot \mathrm{L}^{-1} \mathrm{P}\right)$ or $4\left(5\right.$ to $\left.40 \mathrm{mg} \cdot \mathrm{L}^{-1} \mathrm{P}\right)$ samples (individual plants) per replication. ${ }^{* * *}$ indicates significance at $P \leq 0.001$.

varied to achieve target $\mathrm{P}$ concentrations for a range of $\mathrm{P}$ concentrations in the fertilizer treatments during the finishing stage of growth. Post-transplant and throughout production, plants were individually provided with their respective fertilizer solutions at each irrigation event. To attain a minimal leaching fraction and avoid overwatering and oversaturation of $\mathrm{P}$ in low-P treatment groups, sub-replicates were irrigated as needed instead of irrigating all plants within a given replication (groups of four plants per treatment per species); plants were never allowed to reach the point of incipient wilting.

Plants were grown in the greenhouse as previously described. The air temperature was measured every $15 \mathrm{~s}$ by four temperature probes (41342; R.M. Young Company, Traverse City, MI) in an aspirated radiation shield (43502; R.M. Young Company), whereas the $P P F D$ was measured every
$15 \mathrm{~s}$ by eight quantum sensors (LI-190SL; LI-COR Biosciences) per greenhouse. Temperature probes and quantum sensors were connected to a data logger (CR1000 Measurement and Control System; Campbell Scientific, Logan, UT), with means logged every $15 \mathrm{~min}$. The mean day, night, and daily temperatures were $23.0 \pm 1.5,24.3 \pm 1.5$, and $20.1 \pm 1.6{ }^{\circ} \mathrm{C}$, respectively, and the mean DLI was $11.4 \pm 1.9 \mathrm{~mol} \cdot \mathrm{m}^{-2} \cdot \mathrm{d}^{-1}$ during the experiment. 


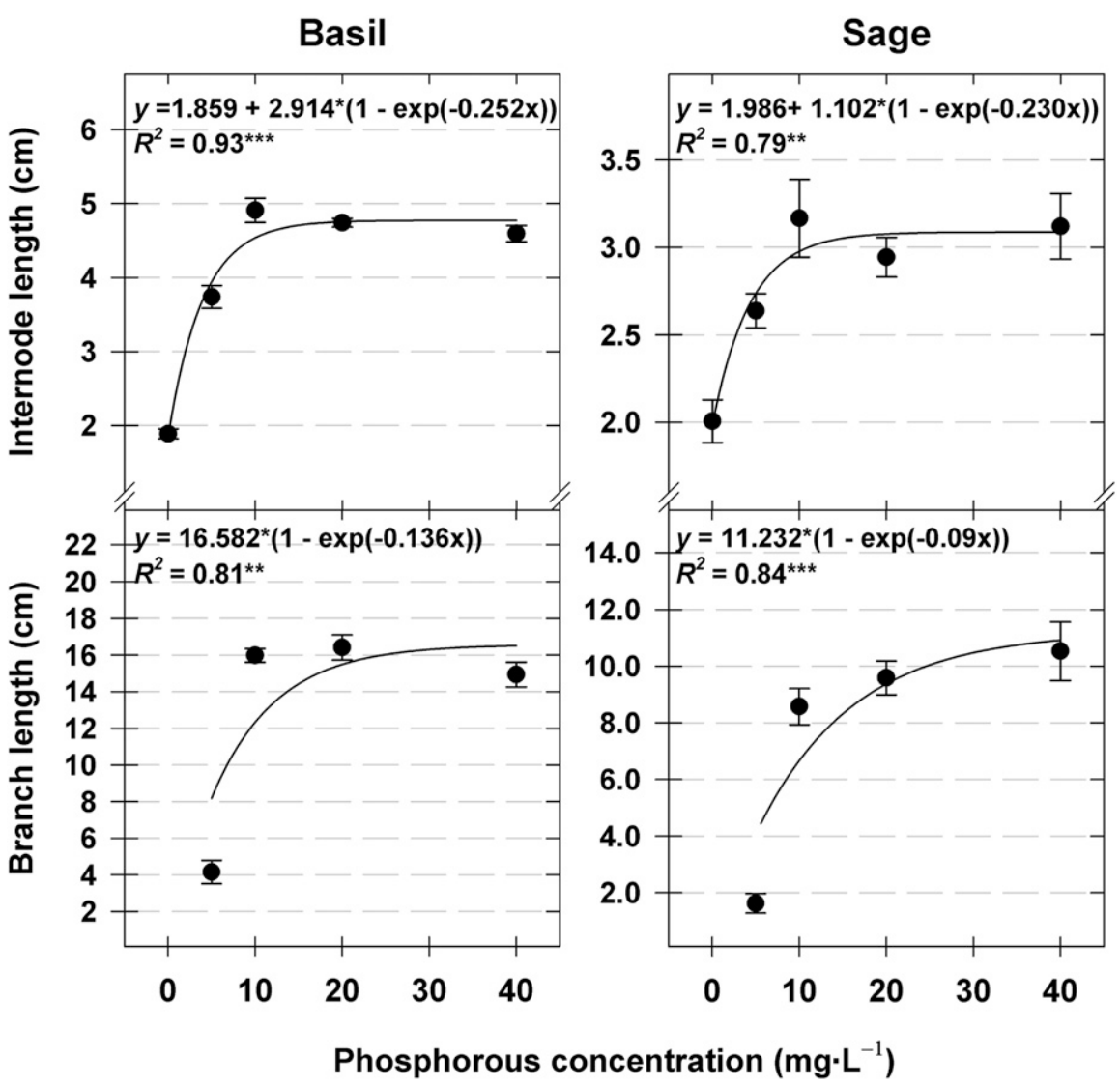

Fig. 3. Internode and branch length of sweet basil (Ocimum basilicum 'Italian Large Leaf') and sage (Salvia officinalis) grown in 11.4-cm-diameter containers and provided with nutrient solutions containing 0 to $40 \mathrm{mg} \cdot \mathrm{L}^{-1}$ phosphorous (P). Data were collected 4 weeks after transplanting seedlings. Each symbol represents the mean of four replications, with each consisting of $8\left(0 \mathrm{mg} \cdot \mathrm{L}^{-1} \mathrm{P}\right)$ or $4(5$ to $40 \mathrm{mg} \cdot \mathrm{L}^{-1} \mathrm{P}$ ) samples (individual plants) per replication. ** or *** indicate significance at $P \leq 0.01$ or 0.001 , respectively.

Four weeks after transplanting seedlings, 80 to $100 \mathrm{~mL}$ of reverse osmosis water was applied to the substrate surface of containers $1 \mathrm{~h}$ following irrigation with $\mathrm{P}$ solutions to collect $\approx 50 \mathrm{~mL}$ of leachate. The $\mathrm{pH}$ and electrical conductivity (EC) of the leachate were measured using a portable $\mathrm{pH}$ and $\mathrm{EC}$ meter (HI9813-6 pH/EC/TDS/Temperature Meter; Hanna Instruments, Smithfield, RI). Height from the surface of the substrate to the tallest-growing unfolded leaf, widths at the widest point and $90^{\circ}$ perpendicular to that point, and length of a branch at the thirdoldest or fourth-oldest node were measured and nodes were counted. For sweet basil and sage, the internode length was calculated by dividing the height by the number of nodes. A leaf from the third or fourth most recently matured node was removed from each plant and placed in a leaf area meter (LI-COR 3100; LI-COR Biosciences). Shoots were severed at the surface of the substrate, triple-washed in deionized water, placed in a paper bag, and dried in a forced-air oven for $3 \mathrm{~d}$; then, shoots were weighed and the dry mass was recorded. The $\mathrm{pH}$ and EC of a random sample (individual plant) were measured for each replication, whereas growth data were collected for all samples in each replication.
Shoots were sent to a commercial laboratory to quantify macro- and micronutrient shoot concentrations. Dried shoot tissue was analyzed to determine nutrient concentrations. The determination of Kjeldahl nitrogen for all tissue samples began with standard digestion in concentrated sulfuric acid at $360{ }^{\circ} \mathrm{C}$ for $\approx 1.5 \mathrm{~h}$ using a Tecator 40 block digestor. The resultant ammonium fraction was measured with a flow-injection analyzer (QuickChem 8500; Lachat Instruments) using a buffered salicylate-hypochlorite solution for color development. The determination of $\mathrm{P}$, potassium $(\mathrm{K})$, calcium $(\mathrm{Ca}), \mathrm{Mg}, \mathrm{S}$, zinc $(\mathrm{Zn})$, manganese $(\mathrm{Mn})$, copper $(\mathrm{Cu})$, iron $(\mathrm{Fe})$, and boron $(\mathrm{B})$ in all tissue samples began with initial digestion in concentrated nitric acid at $90{ }^{\circ} \mathrm{C}$, followed by three small additions of $30 \%$ hydrogen peroxide; the total time for digestion was $\approx 1 \mathrm{~h}$. Digested samples were filtered and analyzed by inductively coupled plasma-optical emission spectroscopy (Optima 4300 DV; Perkin Elmer).

The experiment used a randomized complete block design for each species. There were four replications (blocks of four plants) for each $\mathrm{P}$ concentration for each species, with four samples (individual plants) per replication for all $\mathrm{P}$ treatments $\geq 5 \mathrm{mg} \cdot \mathrm{L}^{-1}$.
There were eight samples per replication for $0 \mathrm{mg} \cdot \mathrm{L}^{-1} \mathrm{P}$ to ensure sufficient leaf tissue for nutrient analyses. Data were analyzed using regression analyses (Sigma Plot 21.0; Systat Software, San Jose, CA) with the P concentration as the independent variable.

\section{Results}

Sweet basil. As P increased from 0 to 20 $\mathrm{mg} \cdot \mathrm{L}^{-1}$, the substrate $\mathrm{pH}$ increased from 6.3 to 6.9 ; furthermore, increasing $\mathrm{P}$ to $40 \mathrm{mg} \cdot \mathrm{L}^{-1}$ resulted in a $\mathrm{pH}$ of 6.5 (Fig. 1). Alternatively, as $\mathrm{P}$ increased from 0 to 20 , the substrate EC decreased from 2.7 to $1.4 \mathrm{dS} \cdot \mathrm{m}^{-1}$ (Fig. 1). Whereas plants provided with $0 \mathrm{mg} \cdot \mathrm{L}^{-1} \mathrm{P}$ had 5.3 nodes, increasing $P$ to 5 or 10 to 40 $\mathrm{mg} \cdot \mathrm{L}^{-1} \mathrm{P}$ increased the node number to 7.9 or 8.7 to 8.8 nodes, respectively (Fig. 2). Height increased from $9.9 \mathrm{~cm}$ at $0 \mathrm{mg} \cdot \mathrm{L}^{-1} \mathrm{P}$, and it increased up to $42.5 \mathrm{~cm}$ at $20 \mathrm{mg} \cdot \mathrm{L}^{-1}$; height did not increase further with higher $\mathrm{P}$ concentrations (Fig. 2). Sweet basil provided with 5 or 10 to $40 \mathrm{mg} \cdot \mathrm{L}^{-1} \mathrm{P}$ had internodes $3.7 \mathrm{~cm}$ or 4.6 to $4.9 \mathrm{~cm}$ longer than plants provided with $0 \mathrm{mg} \cdot \mathrm{L}^{-1} \mathrm{P}$ (Fig. 3). The leaf area increased from 6.3 to $58.2 \mathrm{~cm}^{2}$ as $\mathrm{P}$ increased from 0 to $10 \mathrm{mg} \cdot \mathrm{L}^{-1}$. Sweet basil fertilized with $0 \mathrm{mg} \cdot \mathrm{L}^{-1} \mathrm{P}$ had no branches (data not shown), but the branch length increased from $4.2 \mathrm{~cm}$ for plants fertilized with $5 \mathrm{mg} \cdot \mathrm{L}^{-1} \mathrm{P}$ up to 16.0 to $14.9 \mathrm{~cm}$ for plants fertilized with 10 to $40 \mathrm{mg} \cdot \mathrm{L}^{-1} \mathrm{P}$. At 0 $\mathrm{mg} \cdot \mathrm{L}^{-1} \mathrm{P}$, shoot dry mass was $0.8 \mathrm{~g}$; it increased up to 6.1 to $6.4 \mathrm{~g}$ when 20 to 40 $\mathrm{mg} \cdot \mathrm{L}^{-1} \mathrm{P}$ was applied (Fig. 2). Tissue concentrations of both $\mathrm{N}$ and $\mathrm{P}$ increased linearly from $3.7 \%$ and $0.1 \%$, respectively, at 0 $\mathrm{mg} \cdot \mathrm{L}^{-1} \mathrm{P}$ to $4.4 \%$ and $0.8 \%$, respectively, at $40 \mathrm{mg} \cdot \mathrm{L}^{-1}$ (Fig. 4). Tissue K, Mg, S and B increased quadratically by $1.4 \%, 0.3 \%$, $0.18 \%$, and $7.1 \mathrm{mg} \cdot \mathrm{kg}^{-1}$ respectively, as $\mathrm{P}$ increased from 0 to $40 \mathrm{mg} \cdot \mathrm{L}^{-1}$, whereas $\mathrm{Zn}$, $\mathrm{Mn}$, and Fe decreased quadratically by 66,4 , and $87 \mathrm{mg} \cdot \mathrm{kg}^{-1}$, respectively. Neither $\mathrm{Ca}$ $(2.5 \%)$ nor $\mathrm{Cu}(7.5 \mathrm{ppm})$ was affected by $\mathrm{P}$ (Figs. 4 and 5).

Dill. Although substrate $\mathrm{pH}$ quadratically increased in response to the increasing $\mathrm{P}$ concentration, the EC decreased (Fig. 1). The node number, height, width, shoot dry mass, and leaf area all increased with increasing $\mathrm{P}$ concentrations, although the increase in growth was usually saturated at between 10 and $20 \mathrm{mg} \cdot \mathrm{L}^{-1} \mathrm{P}$, and further increasing $\mathrm{P}$ had no effect (Fig. 2). For example, dill provided with 0,5 , or 10 to 40 $\mathrm{mg} \cdot \mathrm{L}^{-1} \mathrm{P}$ had $\approx 5.2,7.4$, or 9.0 nodes, respectively. Similarly, the height increased from 9.4 to $26.5 \mathrm{~cm}$ as $\mathrm{P}$ increased from 0 to 10 $\mathrm{mg} \cdot \mathrm{L}^{-1}$, and the width increased from 6.9 to $19.5 \mathrm{~cm}$; height and width were not promoted with $>10 \mathrm{mg} \cdot \mathrm{L}^{-1} \mathrm{P}$ (Fig. 2). Leaf area, shoot dry mass, node number, height, and width followed the same trend (Fig. 2). All macronutrients, $\mathrm{Mn}$, and $\mathrm{Fe}$ concentrations in dill shoots increased with increasing $\mathrm{P}$, whereas $\mathrm{Zn}$ and $\mathrm{B}$ decreased; however, $\mathrm{Cu}$ was unaffected by P (Figs. 4 and 5).

Parsley. The substrate $\mathrm{pH}$ increased from 6.3 to 6.7 as $\mathrm{P}$ increased from 0 to $20 \mathrm{mg} \cdot \mathrm{L}^{-1}$ 
Basil

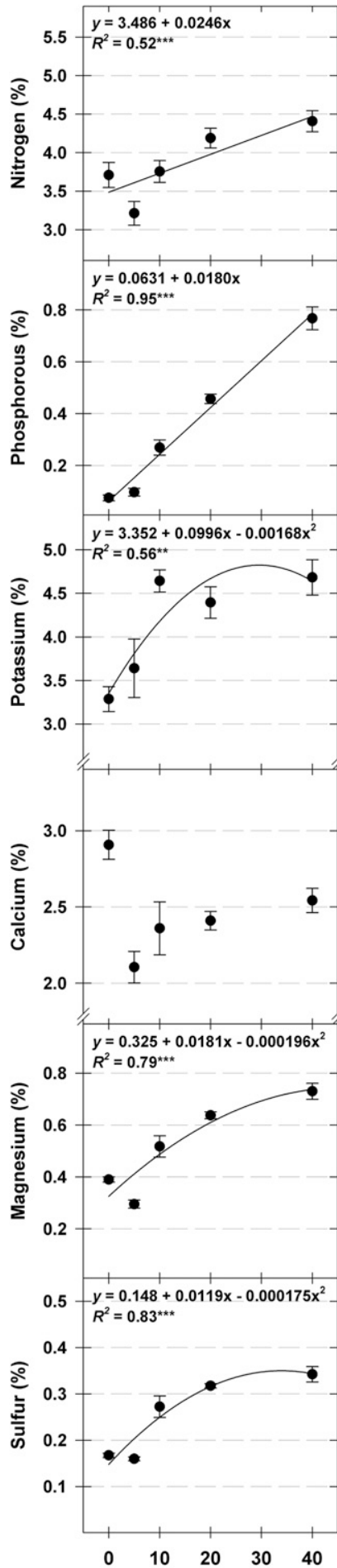

Dill
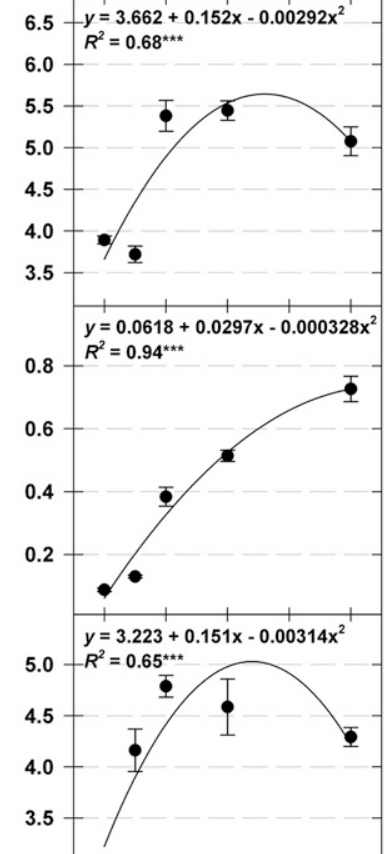

3.

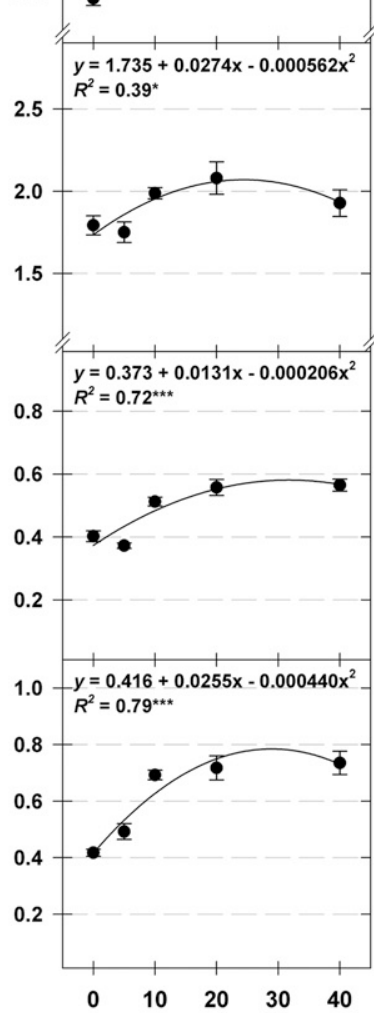

Parsley
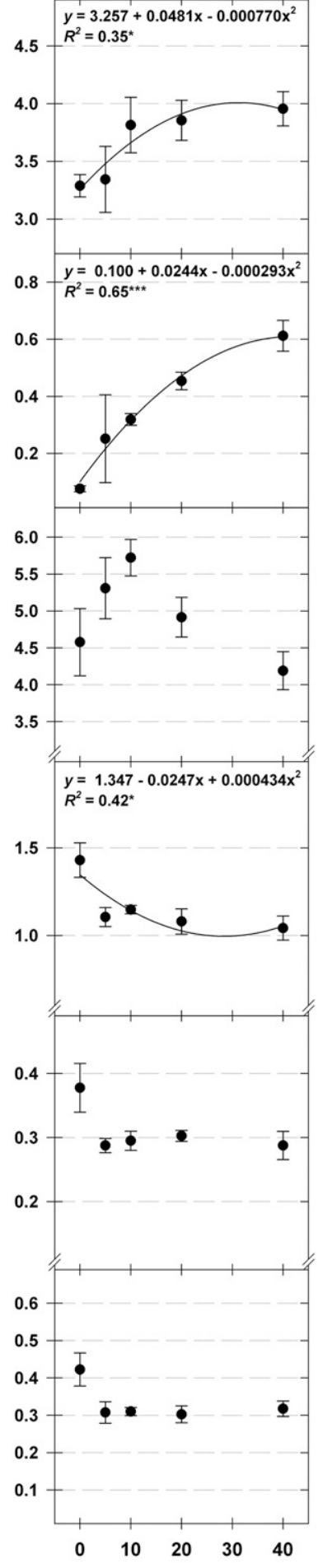

Sage

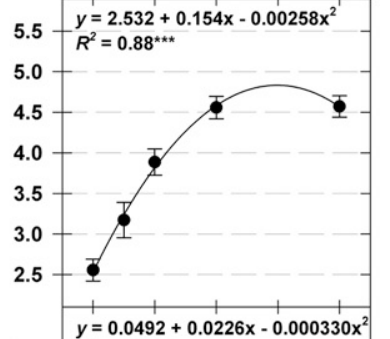

$0.5-\begin{aligned} y & =0.0492+ \\ R^{2} & =0.96^{\star \star \star}\end{aligned}$
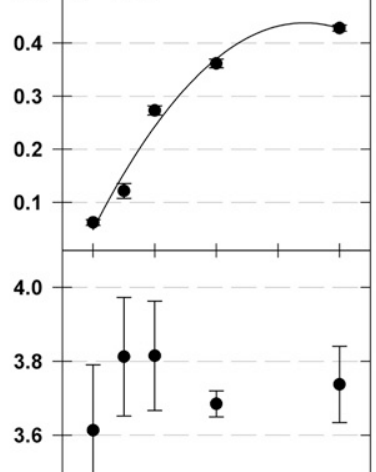

3.4

$y=1.191+0.0596 x-0.00102 x^{2}$
$R^{2}=0.85^{\star \star * x}$

$2.5-R^{2}=0.85^{\star \star *}$

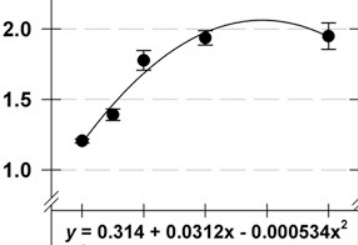

$R^{2}=0.84^{\star \star \star *}$

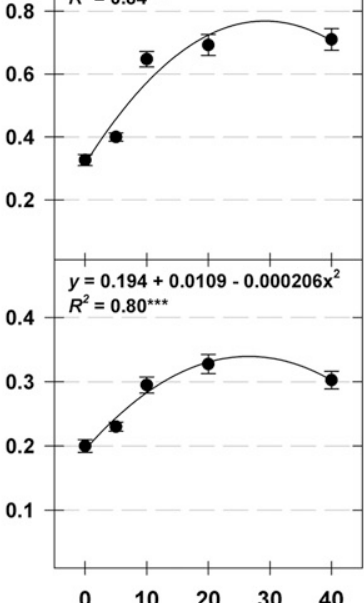

Phosphorous concentration $\left(\mathrm{mg} \cdot \mathrm{L}^{-1}\right)$

Fig. 4. Nitrogen, phosphorous, potassium, calcium, magnesium, and sulfur concentrations of sweet basil (Ocimum basilicum 'Italian Large Leaf'), dill (Anethum graveolens 'Fernleaf'), parsley (Petroselinum crispum 'Giant of Italy'), and sage (Salvia officinalis) grown in 11.4-cm-diameter containers and provided with nutrient solutions containing 0 to $40 \mathrm{mg} \cdot \mathrm{L}^{-1}$ phosphorous (P). Data were collected 4 weeks after transplanting seedlings. Each symbol represents the mean of four replications, with each consisting of $8\left(0 \mathrm{mg} \cdot \mathrm{L}^{-1} \mathrm{P}\right)$ or $4\left(5\right.$ to $\left.40 \mathrm{mg} \cdot \mathrm{L}^{-1} \mathrm{P}\right)$ samples (individual plants) per replication. Regression lines are only presented for statistically significant responses. *, **, or *** indicate significance at $P \leq 0.05,0.01$, or 0.001 , respectively.

and to 6.5 at $40 \mathrm{mg} \cdot \mathrm{L}^{-1}$, whereas $\mathrm{EC}$ decreased from 2.5 to $1.1 \mathrm{dS} \cdot \mathrm{m}^{-1}$ (Fig. 1). As P increased above $0 \mathrm{mg} \cdot \mathrm{L}^{-1}$ (4.5 nodes), the node number increased from $6.5\left(5 \mathrm{mg} \cdot \mathrm{L}^{-1} \mathrm{P}\right)$ to 8.3 (40 $\mathrm{mg} \cdot \mathrm{L}^{-1} \mathrm{P}$; Fig. 1). Height increased with $\mathrm{P}$ ranging from $0 \mathrm{mg} \cdot \mathrm{L}^{-1}(7.3 \mathrm{~cm})$ to 20 $\mathrm{mg} \cdot \mathrm{L}^{-1}(23.5 \mathrm{~cm})$; there was no effect with additional $\mathrm{P}$ concentrations. Similarly, width increased by $23.7 \mathrm{~cm}$ as $\mathrm{P}$ increased from 0 up to $20 \mathrm{mg} \cdot \mathrm{L}^{-1}$. The leaf area increased with
P concentrations from $4.1 \mathrm{~cm}^{2}$ at $0 \mathrm{mg} \cdot \mathrm{L}^{-1}$ to $98.7 \mathrm{~cm}^{2}$ at $40 \mathrm{mg} \cdot \mathrm{L}^{-1}$. Shoot dry mass increased from 0.09 to $1.4 \mathrm{~g}$ as $\mathrm{P}$ increased from 0 to $40 \mathrm{mg} \cdot \mathrm{L}^{-1}$. Tissue $\mathrm{N}$ and $\mathrm{P}$ increased quadratically with $\mathrm{P}$, whereas $\mathrm{Ca}, \mathrm{Fe}$, 
Basil

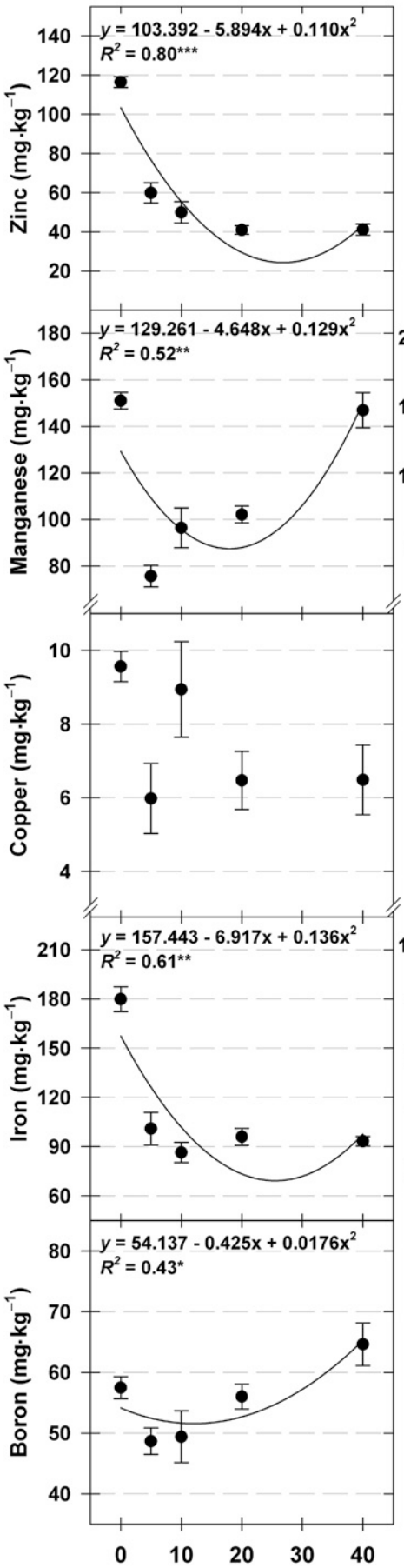

Dill

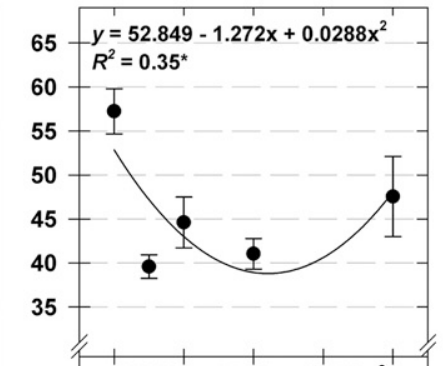

200.

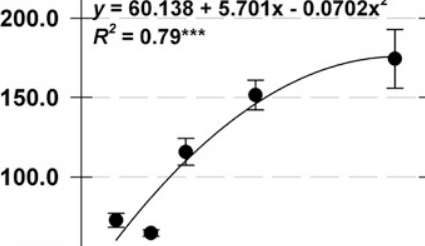

50.0
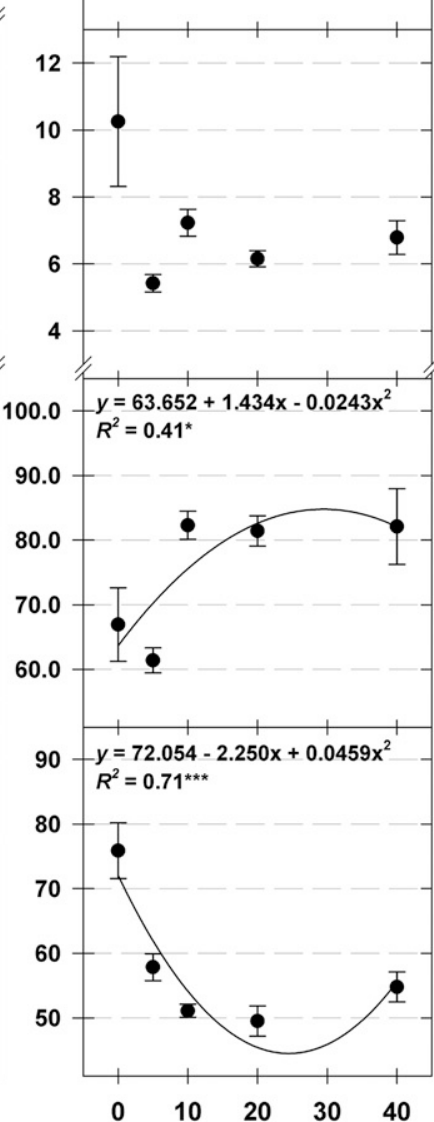

Parsley
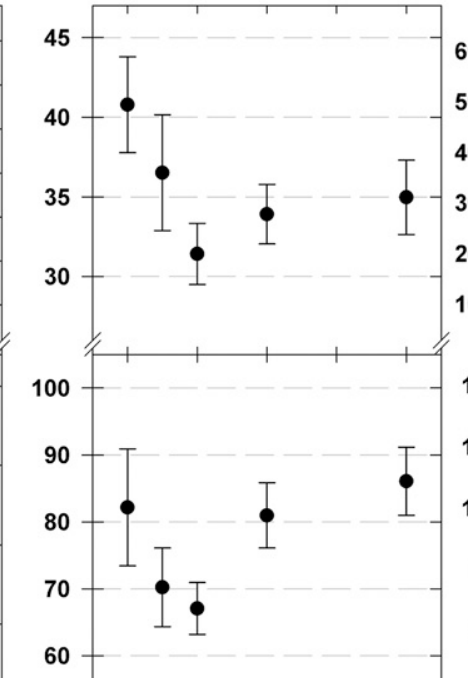

$$
\begin{aligned}
& 60 \\
& 6.5 \\
& 6.0 \\
& 5.5 \\
& 5.0 \\
& 4.5
\end{aligned}
$$
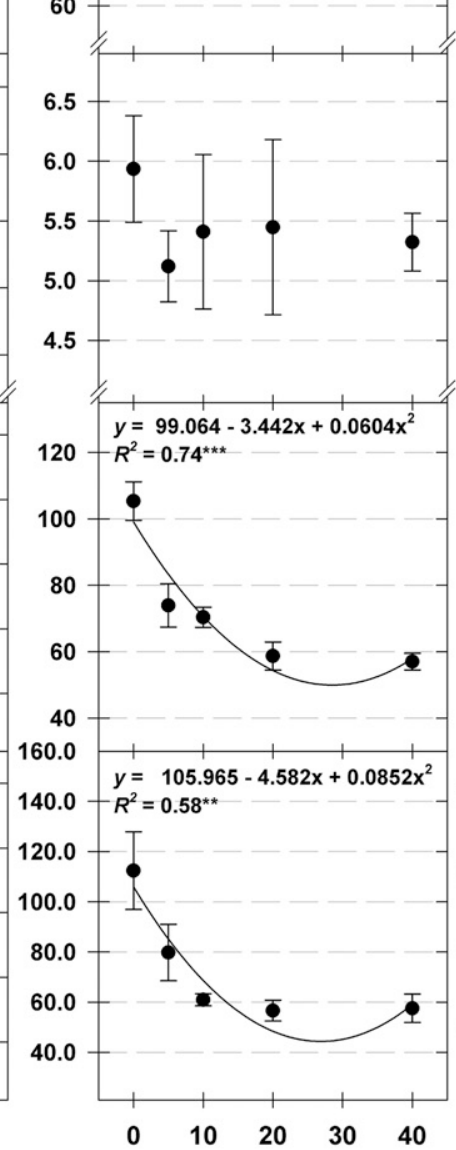

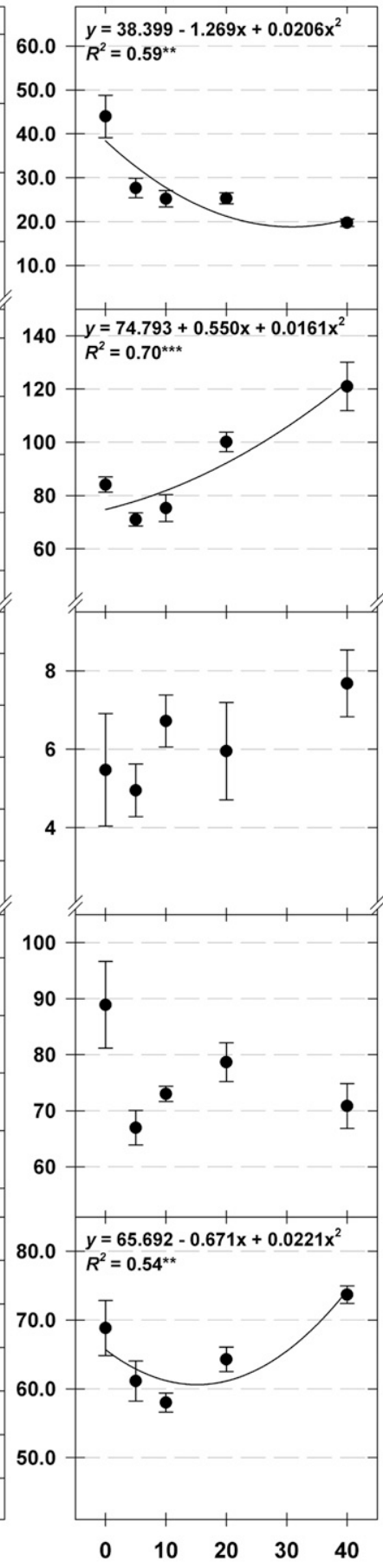

Sage

Phosphorous concentration $\left(\mathrm{mg} \cdot \mathrm{L}^{-1}\right)$

Fig. 5. Zinc, manganese, copper, iron, and boron concentrations of sweet basil (Ocimum basilicum 'Italian Large Leaf'), dill (Anethum graveolens 'Fernleaf'), parsley (Petroselinum crispum 'Giant of Italy'), and sage (Salvia officinalis) grown in 11.4-cm-diameter containers and provided with nutrient solutions containing 0 to $40 \mathrm{mg} \cdot \mathrm{L}^{-1}$ phosphorous (P). Data were collected 4 weeks after transplanting seedlings. Each symbol represents the mean of four replications, with each consisting of $8\left(0 \mathrm{mg} \cdot \mathrm{L}^{-1} \mathrm{P}\right)$ or $4\left(5\right.$ to $\left.40 \mathrm{mg} \cdot \mathrm{L}^{-1} \mathrm{P}\right)$ samples (individual plants) per replication. Regression lines are only presented for statistically significant responses. *,**, or *** indicate significance at $P \leq 0.05,0.01$, or 0.001 , respectively.

and $\mathrm{B}$ decreased quadratically with $\mathrm{P} ; \mathrm{K}$ (4.9\%), Mg (0.3\%), S (0.3\%), Zn (35.5 $\left.\mathrm{mg} \cdot \mathrm{kg}^{-1}\right), \mathrm{Mn}\left(77.3 \mathrm{mg} \cdot \mathrm{kg}^{-1}\right)$, and $\mathrm{Cu}(5.4$ $\mathrm{mg} \cdot \mathrm{kg}^{-1}$ ) levels were unaffected by the $\mathrm{P}$ concentration.

Sage. Substrate $\mathrm{pH}$ and EC were affected differently by $\mathrm{P}$ concentrations; although $\mathrm{pH}$ increased quadratically with $\mathrm{P}$ concentra- tions, the EC decreased (Fig. 1). The node number increased from 5.3 for plants provided with $0 \mathrm{mg} \cdot \mathrm{L}^{-1} \mathrm{P}$ to 8.3 nodes for plants provided with $20 \mathrm{mg} \cdot \mathrm{L}^{-1} \mathrm{P}$. Both height (Fig. 2) and internode length (Fig. 3) increased with $\mathrm{P}$ concentration, with height increasing by $13.8 \mathrm{~cm}(131 \%)$ as $\mathrm{P}$ increased from 0 to $20 \mathrm{mg} \cdot \mathrm{L}^{-1}$ and internode length increasing by $1.2 \mathrm{~cm}(58 \%)$ as $\mathrm{P}$ increased from 0 to $10 \mathrm{mg} \cdot \mathrm{L}^{-1}$; however, $\mathrm{P}$ did not promote height and internode extensions above 20 and $10 \mathrm{mg} \cdot \mathrm{L}^{-1}$, respectively. Width, leaf area, and branch length followed a similar trend and increased with $\mathrm{P}$ concentrations up to $10 \mathrm{mg} \cdot \mathrm{L}^{-1}$ (width; Fig. 2) or $20 \mathrm{mg} \cdot \mathrm{L}^{-1}$ (leaf area and branch length; Figs. 2 and 3). 
Shoot dry mass increased from 0.3 to $1.2 \mathrm{~g}$ as $\mathrm{P}$ increased from 0 to $40 \mathrm{mg} \cdot \mathrm{L}^{-1}$. Sage tissue $\mathrm{N}, \mathrm{P}, \mathrm{Ca}, \mathrm{Mg}$, and $\mathrm{S}$ increased with increasing $\mathrm{P}$ concentrations, whereas $\mathrm{Zn}$ decreased; $\mathrm{K}$ (3.7\%), $\mathrm{Cu}\left(6.2 \mathrm{mg} \cdot \mathrm{kg}^{-1}\right)$, and $\mathrm{Fe}(75.0$ $\left.\mathrm{mg} \cdot \mathrm{kg}^{-1}\right)$ were unaffected by $\mathrm{P}$.

\section{Discussion}

Sweet basil, dill, parsley, and sage growth increased as the P concentration increased, and they were generally saturated when grown using fertilizer solutions containing between 10 and $20 \mathrm{mg} \cdot \mathrm{L}^{-1} \mathrm{P}$. As previously stated, we have found no research quantifying the effects of $\mathrm{P}$ on containerized herb growth. However, we can look to the literature reporting the effects of $\mathrm{P}$ on containerized floriculture plants (Frantz, 2013; Henry et al., 2017, 2018a; Justice and Faust, 2015). For example, containerized vinca (Catharanthus roseus 'Cooler Grape') and zinnia (Zinnia elegans 'Oklahoma White') given 12.4 to $495.5 \mathrm{mg} \cdot \mathrm{L}^{-1} \mathrm{P}$ are largest when provided with $\geq 61.9 \mathrm{mg} \cdot \mathrm{L}^{-1} \mathrm{P}$, and concentrations below this level suppress the plant size. (Frantz, 2013). Justice and Faust (2015) reported withholding $\mathrm{P}$ during propagation and in the starter charge at transplanting and applying low $\mathrm{P}$ concentrations $\left(0-6 \mathrm{mg} \cdot \mathrm{L}^{-1}\right)$ produced height-suppressed hybrid impatiens (Impatiens $\times$ hybrida 'Sunpatiens Compact Lilac') compared with plants provided with ample $\mathrm{P}$ throughout propagation and finishing. Henry et al. (2017) conducted a series of experiments exploring $P$ restrictions for container-grown crop fertilization. In two experiments, continuous fertilization with solutions containing $5 \mathrm{mg} \cdot \mathrm{L}^{-1} \mathrm{P}$ suppressed new guinea impatiens (Impatiens hawker 'Pure Beauty Red On Pink' and 'Tamarinda Dark Red') and petunia (Petunia atkinsiana 'Potunia Neon' and 'Surprise Sun Blue') growth compared with plants provided with up to 20 and $80 \mathrm{mg} \cdot \mathrm{L}^{-1} \mathrm{P}$, respectively. Additionally, although stopping $\mathrm{P}$ application altogether results in $\mathrm{P}$ deficiency symptoms of ornamental pepper (Capsicum annuum 'Tango Red'), continuous fertilization providing 2.5 or $5 \mathrm{mg} \cdot \mathrm{L}^{-1}$ produces acceptable, yet compact, growth compared with plants provided with 10 or $20 \mathrm{mg} \cdot \mathrm{L}^{-1} \mathrm{P}$ (Henry et al., 2017). Henry et al. (2018a) also reported that angelonia (Angelonia angustifolia 'Sungelonia Blue' and 'Sungelonia White') provided with 2.5 or $5 \mathrm{mg} \cdot \mathrm{L}^{-1}$ continuous $\mathrm{P}$ fertilization were comparable in size to plants continually provided with growth-saturating $\mathrm{P}$ concentrations (10 or $\left.20 \mathrm{mg} \cdot \mathrm{L}^{-1}\right)$. The results of our research align well with these findings. In our study, 5 $\mathrm{mg} \cdot \mathrm{L}^{-1} \mathrm{P}$ produced plants smaller than those provided with more $\mathrm{P}$, similar to the results of Frantz (2013), Henry et al., (2017, 2018a), and Justice and Faust (2015). However, unlike those studies, $\mathrm{P}$ concentrations $<5$ $\mathrm{mg} \cdot \mathrm{L}^{-1}$ were not included in the present study. Future research of $P$ restriction and containerized culinary herbs would benefit from exploring $\mathrm{P}$ concentrations between 0 and $5 \mathrm{mg} \cdot \mathrm{L}^{-1}$.
The presence of $\mathrm{P}$ deficiency symptomology varied with $\mathrm{P}$ treatments. We observed typical symptomology of deficient tissue $\mathrm{P}$ concentrations such as severe stunting and lower-leaf purpling (Gibson et al., 2007; Morgan, 2005; Whipker et al., 2018) when sweet basil, dill, parsley, and sage were provided with $0 \mathrm{mg} \cdot \mathrm{L}^{-1} \mathrm{P}$. However, there were no deficiency symptoms observed when these species were provided with $\geq 5 \mathrm{mg} \cdot \mathrm{L}^{-1}$ $\mathrm{P}$, regardless of tissue $\mathrm{P}$ concentrations (Figs. 4 and 5). Furthermore, when tissue concentrations of nutrients such as $\mathrm{N}$ for sweet basil and sage provided with $5 \mathrm{mg} \cdot \mathrm{L}^{-1}$ $P$ were below sufficiency ranges found in the literature (Bryson et al., 2014), deficiency symptoms were absent. This may suggest that current published tissue ranges are more restrictive than required. Alternatively, these species may, in fact, have deficient nutrient concentrations, and the lack of visible symptoms may be a function of the relatively short propagation ( 3 to 4 weeks for plugs; Gibson et al., 2000) and finished production time (3 to 4 weeks from transplant to finish; Nau, 2011) for many seed-propagated herbaceous containerized herbs.

Low P fertilization at the concentrations providing desirable growth control may negatively affect flowering by delaying the time to flower or flower number, appearance, and quality (Frantz, 2013; Henry et al., 2018b). However, these risks are limited to when restricting $\mathrm{P}$ as a growth control method for containerized culinary herbs because many of the species are used for their foliage and flowers are usually considered undesirable (Morgan, 2005; van Wyk, 2014). That is not to say there are no risks in marketing plants with deficient tissue values. Marketing and selling plants that appear healthy but are deficient in tissue mineral nutrient concentrations likely pose different risks depending on how products are used by consumers. For containerized herbs that are purchased and harvested for consumption soon thereafter, $\mathrm{P}$ restriction likely poses minimal risk to the postharvest quality, whereas those containerized herbs that are transplanted to larger containers or garden beds may eventually develop visible deficiencies.

Although the impact of low-P tissue nutrient concentrations varied from species to species of containerized culinary herbs in this experiment, substrate $\mathrm{pH}$ was lower and EC was greater when $\mathrm{P}$ was restricted for all species (Fig. 1). Because plants grown at lower $\mathrm{P}$ concentrations were smaller, there was likely lower fertilizer utilization and more residual fertilizer salts in the substrate, which were reflected in the higher EC values for these plants. With increasing $\mathrm{P}$ concentrations, fertilizer uptake likely increased with increasing growth, as reflected by lower EC values. Providing between 50 and 100 $\mathrm{mg} \cdot \mathrm{L}^{-1} \mathrm{~N}$ to complete, balanced watersoluble fertilizer can produce marketable container-grown culinary herbs and minimize unwanted, excessive growth (Flax and Currey, 2016). This fact and the increased EC at low $\mathrm{P}$ suggest that lower fertilizer concen- trations, specifically $\mathrm{N}$, may be warranted when growth is suppressed by restricting $\mathrm{P}$. Additionally, we attribute the increasing $\mathrm{pH}$ with increasing $\mathrm{P}$ concentrations to increased nutrient uptake, specifically $\mathrm{N}$. All of the $\mathrm{N}$ in our fertilizer solutions was provided as $\mathrm{NO}_{3}{ }^{-}$, and this $\mathrm{N}$ form in fertilizers has a basic reaction in the substrate because $\mathrm{NO}_{3}{ }^{-}$uptake releases $\mathrm{OH}^{-}$, thereby increasing the substrate pH (Argo and Biernbaum, 1997; Johnson et al., 2013). Further research of the relationships between $\mathrm{N}$ concentrations and substrate $\mathrm{pH}$ with $\mathrm{P}$ concentrations are warranted to determine interactive effects on managing containerized herb growth and development.

Although the central focus of this research and interpretation of results are primarily focused on restricting $\mathrm{P}$ to control growth, plant responses to $\mathrm{P}$ concentrations also demonstrate a saturation in the growth-promoting effects of P. Broadly speaking, sweet basil, dill, parsley, and sage growth was saturated between 10 and $20 \mathrm{mg} \cdot \mathrm{L}^{-1} \mathrm{P}$. This also agreed with growth responses to high $\mathrm{P}$ concentrations found by Frantz (2013) and Henry et al. (2017, 2018a). According to published production guidelines (Nau, 2011), when the species in this study were provided with fertilizer at the recommended $\mathrm{N}$ concentration $\left(100-150 \mathrm{mg} \cdot \mathrm{L}^{-1} \mathrm{~N}\right)$ and formulation (20-4.4-16.6) for container-crop production, they were provided with approximately onetime to two-times the $\mathrm{P}$ concentrations that saturate growth responses. Therefore, reducing $\mathrm{P}$ to 5 to $10 \mathrm{mg} \cdot \mathrm{L}^{-1}$ can provide growth control. Moreover, $\mathrm{P}$ concentrations that are commonly used could be reduced to achieve additional goals, including reducing $\mathrm{P}$ leaching and conserving $\mathrm{P}$. Because $\mathrm{P}$ is easily leached from soilless substrates commonly used for producing greenhouse crops (Marconi and Nelson, 1984), over-application (i.e., $\mathrm{P}$ concentrations beyond saturating concentrations) may lead to excessive $\mathrm{P}$ leaching during production and unwanted nutrient runoff. Additionally, because the global $\mathrm{P}$ supply is a limited and finite natural resource (Van Vuren et al., 2010), reducing excessive $\mathrm{P}$ application may help conserve this nutrient resource.

\section{Conclusions}

This research is the first to quantify the effect of $\mathrm{P}$ fertilization on the growth and development of sweet basil, dill, parsley, and sage. The growth-promoting effect of $P$ is saturated between 10 and $20 \mathrm{mg} \cdot \mathrm{L}^{-1}$. Providing $<10 \mathrm{mg} \cdot \mathrm{L}^{-1}$ had a growth-regulating effect on the herbs included in this study, and restricting $\mathrm{P}$ to these concentrations can be performed to regulate containerized herb growth in soilless, peat-based media during greenhouse production. Providing $>20$ $\mathrm{mg} \cdot \mathrm{L}^{-1}$ did not benefit herb growth and should be avoided. We are not suggesting that fertilizer solutions with the low P concentrations recommended here should be provided less frequently because that would provide less $\mathrm{P}$ than that provided to plants 
during this experiment, and the resulting effects are unknown. Periodic (i.e., weekly) applications may also be problematic because $\mathrm{P}$ is easily leached from soilless substrates and clear-water application between fertilizer applications would likely diminish the $\mathrm{P}$ available to plants compared with constant liquid fertilization at each irrigation.

\section{Literature Cited}

Alem, P., P.A. Thomas, and M.W. van Iersel. 2015. Use of controlled water deficit to regulate poinsettia stem elongation. HortScience 50:234 239.

Appling, S.M. 2012. Colored shade cloth affects the growth of basil, parsley, and cilantro. M.S. Thesis, Virginia Polytechnic Institute and State Univ., Blacksburg.

Argo, W.R. and J.A. Biernbaum. 1997. Lime, water source, and fertilizer nitrogen form affect substrate- $\mathrm{pH}$ and nitrogen accumulation and uptake. HortScience 32:71-74.

Bryson, G.M., H.A. Mills, D.N. Sasseville, J.B. Jones, and A.V. Barker. 2014. Plant analysis handbook III: A guide to sampling, preparation, analysis, and interpretation for agronomic and horticultural crops. Micro-Macro Publishing, Inc., Athens, GA.

Currey, C.J. and T.Z. Mazur. 2018. Spinning the herb wheel. GrowerTalks 82(4):66, 68-69.

Currey, C.J. 2019. Keeping your herbs under control. GrowerTalks 82(12):62, 64.

Currey, C.J. and R.G. Lopez. 2010. Non-chemical height control. Greenhouse Grower 28(13):24-30.

Currey, C.J., N.J. Flax, A.G. Litvin, and V.C. Metz. 2019. Substrate volumetric water content controls growth and development of containerized culinary herbs. Agronomy 9(11):667.

Erwin, J.E. and R.D. Heins. 1995. Thermomorphogenic responses in stem and leaf development. HortScience 30:940-949.

Flax, N.J. and C.J. Currey. 2016. Controlledrelease and water-soluble fertilizers affect growth and tissue nutrient concentrations of basil, dill, and parsley. HortScience 51:S297 (abstr.).
Frantz, J.M. 2013. Uptake efficiency of phosphorous in different light environments by zinnia. (Zinnia elegans) and vinca (Catharanthus roseus). HortScience 48:594-600.

Gibson, J.L., B.E. Whipker, and R. Cloyd. 2000 Success with container production of 12 herb species. NC State Univ. Horticulture Informational Leaflet 509, Raleigh. 8 p.

Gibson, J.L., D.S. Pitchay, A.L. Williams-Rhodes, B.E. Whipker, P.V. Nelson, and J.M. Dole. 2007. Nutrient deficiencies in bedding plants: A pictorial guide for identification and correction. Ball Publishing, Batavia, IL.

Henry, J.B., I. McCall, B. Jackson, and B.E. Whipker. 2017. Growth response of herbaceous ornamentals to phosphorous fertilization. HortScience 52:1362-1367.

Henry, J.B., I. McCall, and B.E. Whipker. 2018a. Phosphorous restriction as an alternative to plant growth retardants in angelonia and new guinea impatiens. HortTechnology 28:136142.

Henry, J.B., I. McCall, P.V. Nelson, and B.E Whipker. 2018b. Source-sink interactions lead to atypical reproductive stage phosphorus deficiency symptoms on the upper foliage of Capsicum annuum and Chrysanthemum $\times$ morifolium. Scientia Hort. 238:288-294.

Islam, N., S. Torre, A.-B. Wold, and H.R. Gislerød. 2016. Effect of temperature DIF and drop on the growth, quality, total phenolic content and antioxidant activity of herbs. J. Multidisciplinary Engineering Science Studies 2:266-271.

Johnson, C.N., P.R. Fisher, J. Huang, T.H. Yaeger, T.A. Obreza, R.P. Vetanovetz, W.R Argo, and A.J. Bishko. 2013. Effect of fertilizer potential acidity and nitrogen form on the $\mathrm{pH}$ response in a peat-based substrate with three floricultural species. Scientia Hort. $162: 135-143$

Justice, A. and J.E. Faust. 2015. Phosphorousrestriction as a potential technique to control Impatiens stem elongation. Acta Hort. 1104:9-14.

Latimer, J.G. 1998. Mechanical conditioning to control height. HortTechnology 8:529-534.
Marconi, D.J. and P.V. Nelson. 1984. Leaching of applied phosphorous in container media. Scientia Hort. 22:275-285.

Morgan, L. 2005. Fresh culinary herb production: A technical guide to the hydroponic and organic production of commercial fresh gourmet herb crops. Suntec, Tokomaru, New Zealand.

Nau, J. 2011. Part 2: Crop culture, p. 199-736. In: J. Nau (ed.). Ball redbook, vol. 2: Crop production. Ball Publishing, West Chicago, IL.

Nelson, P.V. 2012. Greenhouse operations and management, 7th ed. Prentice Hall, Upper Saddle River, NJ.

Nelson, P.V., C.-Y. Songg, J. Huang, C.E. Niedziela, Jr., and W.H. Swallow. 2012. Relative effects of fertilizer nitrogen form and phosphate level on control of bedding plant seedling growth. HortScience 47:249-253.

Van Vuren, D.P., A.F. Bouwman, and A.H.W Beusen. 2010. Phosphorous demand for the 1970-2100 period: A scenario analysis of resource depletion. Glob. Environ. Change 20:428-439

van Wyk, B.-E. 2014. Culinary herbs and spices of the world. Briza Publications, Pretoria, South Africa.

Whipker, B.E. 2014. Remember the fundamentals of phosphorous nutrition. Greenhouse Grower 31(1):67-68, 71.

Whipker, B.E., I. McCall, and J.G. Latimer. 2011. Growth regulators, p. 95-105. In: J. Nau (ed.). Ball redbook, vol. 2: Crop production. Ball Publishing, West Chicago, IL.

Whipker, B.E., S. Dasoju, M.S. Dosmann, and J.K Iles. 1999. Effect of fertilizer concentration on growth of double impatiens. HortTechnology 9:425-428.

Whipker, B., J. Gibson, and H. Scoggins. 2018. Visual symptoms of nutritional and other disorders, p. 207-224. In: D.J. Merhaut, K.A. Williams, and S.S. Mangiafico (eds.). Water, root media, and nutrient management for greenhouse crops. University of Calif. Agr. Nat. Res., Davis, CA 